\title{
Integrating Task-based Instruction as an Alternative Approach in Teaching Reading Comprehension in English for Special Purposes: An Action Research
}

\author{
Abutaleb Iranmehr \\ Shahrood University of Technology, Shahrood, Iran \\ Email: a_iranmehr946@yahoo.com \\ Seyyed Mahdi Erfani \\ Damghan University, Damghan, Iran \\ Email: smerfani@yahoo.com \\ Hossein Davari \\ Tarbiat Modares University (TMU), Tehran, Iran \\ Email: hdavari1358@yahoo.com
}

\begin{abstract}
Teaching through task or in Willis' (1996) words, "an activity which involves the use of language but in which the focus is on the outcome of the activity rather than on the language used to achieve that outcome" can create favorable learning conditions for the students of English for Specific Purposes (ESP) courses (Kavaliauskiené, 2005). Concerning the current inappropriate teaching methods dominant in Iranian ESP trend, this research aims to investigate the feasibility of integrating task-based language teaching (TBLT) as an alternative to the rather ineffective, yet widely practiced method known as Grammar Translation Method (GTM) on ESP reading comprehension of Iranian students majoring chemistry at two Iranian universities whose syllabus mostly focuses on this skill. To do so, two homogeneous groups as experimental and control at each university served as the participants of the study. Before treatment, pretest was performed in both groups. The participants in the control groups were required to read the texts, translate them into Persian and answer some traditional forms of reading comprehension questions, while the ones in the experimental groups studied the same passages but furnished with some patterns of task-based instruction and accompanied with exercises prepared within Willis' TBLT framework. At the end of the treatment, a post test was administered to them. Finally, drawing on t-test at the 0.05 level of significance, the researchers compared the students' performances to study the probable effectiveness of TBLT. The findings revealed the significant advantage of teaching ESP through tasks and integrating this approach as an innovative one in this trend.
\end{abstract}

Index Terms-ESP, TBLT, reading comprehension, EFL setting

\section{INTRODUCTION}

In English as a Foreign Language (EFL) setting, it is mostly believed that reading comprehension is the central means for learning new information and it is the most important skill needed for the student's success. The importance and position of reading comprehension skill in Iranian academic setting like other EFL settings are undeniable; in a way, it is often introduced as the main goal of English language learning. Therefore, it has attracted the attention of many English Language Teaching (ELT) researchers and applied linguists.

The framework of current ESP textbooks in Iranian academic setting shows that the most important skill the students need for success in their studies is reading (Farhady, 2006 ; Riazi, 2005), but enumerating the significant drawbacks of Iranian ESP textbooks, Erfani et al. (2009) introduce the lack of useful and efficient strategies and enjoying an inflexible and clichéd pattern as serious shortcomings of ESP textbooks developed by SAMT (The Organization for Research and Compiling University Textbooks in Humanities).

The available findings in this area reveal that emphasizing on reading based on traditional approaches and strategies has been the source of new problems. In this case, Hokmi (2005) states that traditionally Iranian students in ESP courses are required to read texts, translate them into Persian, and answer the comprehension questions. According to Shokouhi (2006), inadequate approaches including Grammar Translation Method have been dominant in the current ESP textbooks and classrooms; significant approaches which have shown to be effective in enhancing the learner's understanding have somewhat been neglected in this trend. 
In fact, the problem with traditional approaches is that they do not usually consider as being purpose-driven and comprehension questions generally address all information in the text in an undifferentiated manner as if all ideas or aspects of the text are equally important. In this regard, Farhady (2006) clearly asserts that the activities and exercises in the ESP Iranian textbooks do not give learners a sense of achievement in terms of the reading skill. Tasks are not designed to involve students in the process of learning, so a remodeling of the texts and activities is highly recommended.

Among the recent effective approaches, Task-based Language Teaching, also referred to as Task-based Instruction has become an important approach; in a way, that it is currently known as the dominant teaching approach to language instruction. As Kavaliauskiené (2005) writes, teaching through tasks creates favorable learning conditions for students who study English for specific purposes. In her words, task-based instruction seems to grant meaningful use of language and promote autonomous learning. Introducing task-based instruction as a practical methodology which can be supplemented in EFL textbooks, Finch (2004) asserts that by creating such student-centered and interactive learning materials, teachers can achieve syllabus goals and can help their students to become more motivated and effective learners.

On the one hand, observing such a serious drawback which the current ESP textbooks are suffering from, and on the other hand conceiving the significant stance and effectiveness of Task-based Instruction as an alternative approach in ESP teaching and materials development, this paper intends to introduce the probable advantage of integrating taskbased instruction by incorporating some kinds of educational tasks through action research in an Iranian ESP setting.

Thus, this paper reports the results of an explanatory action research of the integration of Task-based Instruction into ESP reading comprehension ability of university students majoring chemistry based on Willis' TBLT framework (1996) in Damghan and Shahrood Universities, Iran.

\section{STATEMENT OF THE PROBLEM}

ESP courses receive a great deal of attention and emphasis among the EFL practitioners and learners especially at universities. Concerning the importance of ESP textbooks, Mansor (2001) maintains that they have always been an integral part of a syllabus, and that they have served many teachers well, providing them with the pivot onto which their lessons hinge.

Here, due to the problems with traditional approaches applied in ESP textbooks as well as the importance of reading comprehension in English for specific purposes, it seems necessary to investigate whether task-based language teaching as an alternative suggestion has any effect on improving ESP reading comprehension ability of Iranian students.

Here, it is worth noting that action research is known as one of the newly developed methods in ELT. In Crookes' words (1993), in such a research, the research question emerges from the immediate concerns and problems in which the teacher is practicing. Action research is a more practical and user-friendly than research defined in traditional senses. It is conducted research for one main purpose: to improve teaching and learning (Slavin, 2006). In addition, due to its less formal nature, teachers and building administrators will find by far the easiest form of research to conduct. It can involve a single researcher or a collaborative team working together to focus on a mutual topic (Ross-Fisher, 2008). Burns (2009) also introduces action research as an efficient tool for teaching practice enhancement.

As noted, in spite of efficiency of task-based instruction in ESP teaching, the Iranian ESP instructors still follow the traditional approaches specially the GTM. Thus, on the one hand to tackle the immediate problems felt by the ESP teachers in Iranian context and on the other hand to verify the probable advantage of task-based instruction, this study was undertaken through action research to provide an answer to the following research question: Does task-based instruction have any effect on reading comprehension ability of Iranian university students majoring chemistry?

In line with the attempt to determine whether task-based approach has any effect on improving reading comprehension ability, a null hypothesis was formulated: "task-based instruction has no effect on the improvement of ESP reading comprehension of Iranian university students majoring chemistry”.

\section{REVIEW OF LITERATURE}

In this part, firstly it was tried to introduce task-based approach, its essential components, as well as its types and possible outcomes in brief. Then, the Willis' TBLT framework, which was adopted as the framework of this research, is introduced.

\section{A. Task-based Instruction}

Task-based instruction has gained popularity in the field of language teaching since the last decade of 20th century (Sanchez, 2004). In this approach, learners concentrate on meaning rather than form; that is, students carry out a group of communicative tasks instead of doing form-based discrete exercises. Students are expected to express their own ideas, either orally or in a written mode, about the topic of the lesson (Willis, 1996).

Nunan (1991) outlines five characteristics of a task-based approach to language learning:

1. An emphasis on learning to communicate through interaction in the target language.

2. The introduction of authentic texts (teaching materials) into the learning situation. 
3. The provision of opportunities for learners to focus not only on language, but also on the learning process itself.

4. An enhancement of the learner's own personal experience as important contributing elements to classroom learning.

5. An attempt to link classroom language learning with language activities outside the classroom.

Willis (1996) explains that "within the TBL framework, tasks and texts combine to give students a rich exposure to language and also opportunities to use it themselves" (p. 101).

According to Ellis (2006), task is an activity that necessarily involves language. Nunan (1989 \& 2004) and Skehan (1996) clearly wish to restrict the use of tasks to activities where meaning is primary. Willis (1996) has defined the term task as those "activities where the target language is used by the learner for a communicative purpose in order to achieve an outcome" (p. 28).

Cubillo and Brenes (2009) assert that if language learners want to attain objectives of a task, especially if it is part of an ESP course, it must fulfill certain characteristics. Firstly, the task should have an appropriate level of complexity and difficulty. Secondly, in an ESP context, the primary goal of a task should reflect what learners need to do in real-life situations at the workplace. Besides, tasks must be based on authentic materials obtained from written or oral texts which have been adapted to simplify their level of difficulty.

Ellis (2006) cites several authors that propose various designs of framework; however, they all coincide in three principal stages or phases. According to him, the first phase in the framework shown in the above figure is the "pretask" that includes the various activities that teachers and students can undertake before beginning the task. Some of these activities may be asking and answering questions or reading a passage related to the topic. The second phase, i.e. task cycle or "during-task", takes place when the task is selected and learners engage in fulfilling the goals of the task. According to Haseli (2004), in this stage the learners usually perform the task (typically a reading exercise) in pairs or small groups. The final phase is "post-task" and involves procedures for following up on the task performance. Only the "during-task" phase is obligatory in task-based teaching. Options selected from the "pre-task" or post-task" phases are non-obligatory, but can serve a crucial role in ensuring that the task performance is maximally effective for language development.

\section{B. Willis' TBLT Framework: Types and Outcomes}

Willis (1996) has listed some types of TBL tasks which can be implemented in an ESP context. They are:

a. listing: in this case, the instructor takes advantage of learner's prior knowledge on the topic to be developed. The outcome of this activity may be a list of concepts that the instructor collects from the students.

b. ranking items: students rank their most important work duties where the target language is needed. The outcome of this activity may be the information stored according to specific criteria.

c. comparing or contrasting items: in the case of atmosphere, for instance, learners may make comparisons between different layers of the atmosphere. A whole-class discussion about it may be carried out as the outcome of this activity. The outcome of this activity may be the identification of similarities and differences.

d. problem-solving activities: in this task, students may give advice on how to solve common problems at the workplace. The outcome of this activity may be the finding of solutions to problems.

e. sharing personal experiences: those open tasks consist of an exchange of opinions among students. The outcome of this activity may be the exchange of opinions and attitudes.

f. creative tasks: these challenging activities require a higher level of preparation and integration of skills. The outcome of this activity may be the end-product appropriated by the audience.

Conceiving the probable efficiency and advantage of TBLT as an innovative approach, the researchers tried to study the effect of using this approach on ESP reading comprehension of Iranian university students through action research which was conducted at two universities, namely Damghan University and Shahrood University of Technology, Iran.

\section{MEthodology}

\section{A. Participants}

This study involved 75 and 65 students majoring chemistry at Damghan University and Shahrood University of Technology, respectively. These participants were enrolled in ESP course. They were randomly chosen to serve as the experimental and control groups at each university. Damghan University's control and experimental groups were 37 and 38 and these numbers for Shahrood University of Technology were 32 and 33 students respectively. To assess their language proficiency, a standard test of English was given to them and based on their scores they were categorized as intermediate.

\section{B. Design}

Based on the purpose of the study, it followed a quasi-experimental design displaying the following characteristics: two homogeneous groups of intermediate level students served as control and experimental groups at each university. A treatment, namely task based instruction was offered to experimental group and the current traditional method i.e. GTM to control group. Two tests as pretest and posttest were administered in each group. 


\section{Instrumentation}

The first testing instrument was a standard proficiency test. It was a test of 100 questions, 40 items of grammar, 40 vocabulary items and 4 reading comprehension passages each with 5 questions. The time allotted was 100 minutes. This test aimed at controlling the proficiency level of the subjects. The pretest was a ready comprehension test. It consisted of 6 reading passages followed by 30 multiple-choice questions. The post-test which was administered to both groups contained 6 reading passages followed by 30 multiple-choice questions. They were all the same length as the pretest and were from the same source.

\section{PROCEDURE}

To accomplish the purpose of the study, the following procedure was followed. Classes were conducted two hours a week and the study lasted for fourteen weeks. Since the purpose of this study was to compare teaching reading comprehension through some strategies of TBLT in comparison with the traditional one i.e. GTM, the two groups were treated differently.

During the experiment, at each university, the both classes had the same curriculum and the same schedule of instruction, except that in the control group, the students had the conventional learning, that is, the teacher introduced the new words and phrases, and the students began to translate the passages into Persian and answer the traditional comprehension questions and exercises. For the experimental group, the same passages were redesigned by the researchers to fit Willis's task-based framework. Thus, for them the class time was divided into three phases namely, pre-task, task cycle and post-task.

\section{DATA ANALYSIS AND INVESTIGATION OF RESEARCH QUESTION}

The effect of task-based instruction on reading comprehension ability of university students was determined with the pretest-posttest equivalent group design. The pretest was given before students received reading instruction using taskbased instruction. To control for confounding variables, the treatment and control groups were taught using the same instructional methods, except for the task-based instruction. At the end of the treatment, an independent sample t-test was used to analyze the data.

To answer the stated question, after scoring the tests and tabulating the scores for each subject, the results were put under a series of statistical analyses. First of all, the means and standard deviations of the two groups in pretest in Damghan and Shahrood universities were calculated respectively.

TABLE 1:

PRE-TEST RESULTS FOR BOTH GROUPS (DAMGHAN)

\begin{tabular}{|l|l|l|l|}
\hline Groups & N & X & SD \\
\hline Exp. G. & 38 & 16.84 & 1.63 \\
\hline Cont. G. & 37 & 16.27 & 1.60 \\
\hline
\end{tabular}

TABLE 2:

PRE-TEST RESULTS FOR BOTH GROUPS (SHAHROOD)

\begin{tabular}{|l|l|l|l|}
\hline Groups & $\mathbf{N}$ & $\mathbf{X}$ & SD \\
\hline Exp. G. & 32 & 16.81 & 1.67 \\
\hline Cont. G. & 33 & 16.90 & 1.66 \\
\hline
\end{tabular}

The above tables indicate that our two samples at each university had, though not exactly, the same dispersions of means which seemed to be suitable for our purpose in this research. Next, an independent t-test was used to verify the pre-test results on both groups at each university.

TABLE 3:

THE T-VALUE FOR PRE-TESTS OF THE TWO GROUPS (DAMGHAN)

\begin{tabular}{|l|l|l|l|}
\hline t crit. & df & p. & t obs. \\
\hline 1.99 & 73 & 0.13 & -1.52 \\
\hline
\end{tabular}

TABLE 4:

THE T-VALUE FOR PRE-TESTS OF THE TWO GROUPS (SHAHROOD)

\begin{tabular}{|l|l|l|l|}
\hline t crit. & df & p. & t obs. \\
\hline 2.00 & 64 & 0.81 & 0.23 \\
\hline
\end{tabular}

As table 3 shows, the value of the calculated $t$ was -1.52 , less than the value of the t-critical 1.99 at 0.05 level of probability. Similarly, as table 4 shows, the value of the calculated t was 0.23 which was less than the value of the $t-$ critical 2.00 at 0.05 level of probability. Therefore, the two groups at each university had little differences. At the end of the study, the results of computing the means of the pre- and post-test of the control groups indicated that there was some progress in each group. In order to find out the difference, the researchers conducted a matched t-test for both universities. 
TABLE 5:

PAIRED T-TEST FOR CONTROL GROUP (DAMGHAN)

\begin{tabular}{|l|l|l|l|l|l|l|}
\hline Group & X1 & X2 & S1 & S2 & df & t obs. \\
\hline Cont. G. & 16.27 & 20.10 & 1.60 & 1.80 & 36 & -29.18 \\
\hline
\end{tabular}

TABLE 6:

\begin{tabular}{|l|l|l|l|l|l|l|}
\hline Group & X1 & X2 & S1 & S2 & df & t obs. \\
\hline Cont. G. & 16.90 & 20.81 & 1.66 & 1.84 & 32 & -29.35 \\
\hline
\end{tabular}

The results obtained from table 5 indicate significant difference between the control group performances on both tests for each university because at Damghan University the observed $t$ of -29.18 at a probability level of $p \leq 0.05$ exceeded the critical t of 1.99. The same is true for Shahrood University of Technology.

The scores gained from the pre- and post-tests of the experimental groups at both universities were also calculated and the results showed a remarkable difference which confirmed the importance of task-based instruction on Iranian university students' ESP reading comprehension. To be sure of the results, the researchers conducted another paired ttest for both universities.

TABLE 7:

PAIRED T-TEST FOR EXPERIMENTAL GROUP (DAMGHAN)

\begin{tabular}{|l|l|l|l|l|l|l|}
\hline Group & X1 & X2 & S1 & S2 & df & t obs. \\
\hline Exp G. & 16.82 & 23.26 & 1.63 & 1.95 & 37 & -52.21 \\
\hline
\end{tabular}

TABLE 8:

PAIRED T-TEST FOR EXPERIMENTAL GROUP (SHAHROOD)

\begin{tabular}{|l|l|l|l|l|l|l|}
\hline Group & X1 & X2 & S1 & S2 & df & t obs. \\
\hline Exp G. & 16.81 & 22.75 & 1.67 & 2.40 & 31 & -33.12 \\
\hline
\end{tabular}

This time since the t-observed -52.21 at Damghan University and -33.12 at Shahrood University of Technology exceeded the value of t-critical 1.99 and 2.00 respectively at a probability level of $\mathrm{p} \leq 0.05$, supported the idea that taskbased instruction had a significant impact on Iranian university students' ESP reading comprehension.

Then, the means and standard deviations of two groups in the post-test were calculated and the differences between them showed a significant difference between the two groups at each university.

TABLE 9:

POST-TEST RESULTS FOR BOTH GROUPS (DAMGHAN)

\begin{tabular}{|l|l|l|l|}
\hline \multicolumn{4}{|c|}{ POST-TEST RESULTS FOR BOTH GROUPS (DAMGHAN) } \\
\hline Exp. G. & $\mathbf{N}$ & $\mathbf{X}$ & SD \\
\hline Cont. G. & 38 & 23.26 & 1.95 \\
\hline
\end{tabular}

TABLE 10:

POST-TEST RESULTS FOR BOTH GROUPS (SHAHROOD)

\begin{tabular}{|l|l|l|l|}
\hline Groups & N & X & SD \\
\hline Exp. G. & 32 & 22.75 & 2.40 \\
\hline Cont. G. & 33 & 20.81 & 1.84 \\
\hline
\end{tabular}

TABLE 11:

THE T-VALUE FOR POST-TESTS OF THE TWO GROUPS (DAMGHAN)

\begin{tabular}{|l|l|l|l|}
\hline t crit. & df & p. & t obs. \\
\hline 1.99 & 73 & 0.0001 & -7.25 \\
\hline
\end{tabular}

TABLE 12:

THE T-VALUE FOR POST-TESTS OF THE TWO GROUPS (SHAHROOD)

\begin{tabular}{|l|l|l|l|}
\hline t crit. & df & p. & t obs. \\
\hline 2.00 & 64 & 0.0001 & -3.63 \\
\hline
\end{tabular}

Since the t-observed of -7.25 and -3.63 at Damghan University and Shahrood University of Technology respectively exceeded critical $t$ of 1.99 and 2.00 at a probability level of $p \leq 0.05$, the result of the independent $t$-test confirmed the positive relationship between using task-based instruction and reading comprehension of Iranian university students. Thus, it could be claimed that passages accompanied with task-based instruction can be more effective than the ones without them.

To analyze the findings more precisely, it was decided to check the gathered data from another way. First, the mean score of experimental and control groups at both universities in post-test was compared with together. 
TABLE 13:

COMPARING DIFFERENCES BETWEEN TWO GROUPS

\begin{tabular}{|l|l|l|l|l|l|l|}
\hline & Group & N & Mean & S.D. & t & Sig. \\
\hline \multirow{2}{*}{ Pre test } & experimental & 70 & 16.82 & 1.64 & \multirow{2}{*}{0.92} & 0.358 \\
\cline { 2 - 7 } & control & 70 & 16.57 & 1.65 & 2.17 & \multirow{2}{*}{0.000} \\
\hline \multirow{2}{*}{ Post test } & experimental & 70 & 23.02 & 1.84 & \multirow{2}{*}{0.000} \\
\cline { 2 - 7 } & control & 70 & 20.44 & & \\
\hline
\end{tabular}

As the above table shows, $t(139)=-0.92$, there is no statistically significant difference between experimental and control groups in pretest. But $\mathrm{t}(138)=-7.58$ indicates that mean score of the experimental group was more than the mean score of the control group in post test which is statistically significant. Therefore, it could be concluded that there was no difference between two groups before treatment but after instructing via TBLT in experiment group and conventional method in control group, mean score of the experimental group promoted significantly more than the control group.

\section{CONCLUSION AND PEDAGOGICAL IMPLICATIONS}

This study was conducted to probe the plausible advantages of TBLT on Iranian university students' ESP reading comprehension. Comparing achievement of the groups, the researchers found that task-based instruction could have significant effect on improving the ESP reading comprehension of Iranian university students.

Generally speaking, based on the results of this research, the following pedagogical implications might be presented:

First, task-based language teaching, which focuses on the ability to perform a task or activity and not on the explicit teaching of grammatical rules or on vocabulary memorization and has attracted the attention of many researchers, language instructors and syllabus designers, can be an innovative alternative for university ESP classrooms in Iranian context.

Second, the instructor's observation revealed that the procedures used in the experimental group triggered off the students to participate more actively in discussions and devoted more attention and interest to the topic.

Third, in spite of some breakthroughs into ESP materials development, there is no doubt that the current status of ESP in Iran as well as many other EFL contexts seriously suffers from the available textbooks. Certainly ESP materials play a strong role in all ESP programs and the Iranian context is not an exception to the rule. Therefore, we need to redesign the materials and obviously following TBLT can be a solution to this problem.

Fourth, dealing with classroom problems, the researchers can use action research as a practical and user-friendly research which its main purpose is improving teaching and learning. Since it can involve a collaborative team as well as a single researcher to focus on a mutual topic or common problem, it can lead to strengthening the cooperative spirit among the researchers.

Last but not the least, although the lack of task-based textbooks on ESP is clearly felt, ESP teachers themselves can design the tasks. Surely, the tasks designed should take into account the learners' needs and interests.

\section{REFERENCES}

[1] Burns, A. (2009). Doing Action Research in English Language Teaching: A Guide for Practitioners, Routledge.

[2] Crookes, G. (1993). Action Research for Second Language Instructors: Going beyond instructor research. Applied Linguistics. 14 (2), 130-144.

[3] Cubillo, P. C., \& Brenes, C. N. (2009). Using Task-based Instruction in an ESP Course in the Computer Center at the University of Costa Rica. Actualidades Investigativas en Educación, 9(1) 1-25.

[4] Ellis, R. (2006). The Methodology of Task-Based Teaching. Retrieved from FTP: http://www.asian-efl-journal.com.

[5] Erfani, S. M., Iranmehr, A. \& Davari, H. (2009). Iranian ESP Textbooks Drawbacks: A Critical Study. The First International Conference "ESP in Asia": Chongqing University, China.

[6] Farhady, H. (2006). Reflections on and Directions for ESP Materials Development in SAMT, in Kiani \& Khayamdar (eds.) Proceedings of the First National ESP/EAP Conference, vol.3, Tehran, SAMT Publication.

[7] Finch, A. (2004). Supplementing secondary EFL textbooks. Gyeongbuk Secondary English Education, XVI, 96 -107.

[8] Haseli, M. (2004). Two Models Compared: Problem-based Learning and Task-based Learning. ESP world, 3(2).

[9] Hokmi, M. (2005). Iranian ESP Students' Reading Comprehension in Task-based Language Teaching Approach. Roshd FLT, 19 (73).

[10] Kavaliauskiené, G. (2005). Task-based Learning and Learning Outcomes in the ESP Classrooms. Studies about Languages, vol. 7.

[11] Mansor, F. (2001). A case of extra-sensitive perception of ESP. GEMA Online Journal of Language Studies. Vol. 1(1).

[12] Nunan, D. (1989). Designing Tasks for the Communicative Classroom, Cambridge: Cambridge University Press.

[13] Nunan, D. (1991). Language Teaching Methodology: a Textbook for Teachers. New York: Prentice-Hall.

[14] Nunan, D. (2004). Task-based Language Teaching, University of Hong Kong, Cambridge University Press.

[15] Riazi, A. (2005). Features of Quality EAP Textbooks: Insights from Literature and Book Reviews, in Kiani \& Khayamdar (eds.) Proceedings of the First National ESP/EAP Conference, vol.1, Tehran, SAMT Publication.

[16] Ross-Fisher, R. (2008). Action research to improve teaching and learning. Kappa Delta Pi Record, 44 (4), 160-164.

[17] Sanchez, A. (2004). The Task-based Approach in language Teaching, University Of Murcia. IJES, 4(1). 
[18] Shokouhi, H. (2006). A New Discourse Plan for the Iranian University ESP Textbooks. In Kiani \& Khayamdar (eds.) Proceedings of the First National ESP/EAP Conference, vol.3, Tehran, SAMT Publication.

[19] Skehan, P. (1996). Second Language Acquisition Research and Task-based Instruction. In Willis J. \& Wilis D. (eds.) Challenge and Change in Language Teaching. Heinemann.

[20] Slavin, R. (2006). Educational Psychology: theory and practice, 8th edition, Boston ed. Boston: Allyn \& Bacon.

[21] Willis, D. (1996). A Framework for Task-based Learning, London, Longman.

Abutaleb Iranmehr received his MA in TEFL in 1998 from Teacher Training University, Tehran, Iran. He is currently a lecturer of Shahrood University of Technology, Iran. His interests include ESP, materials development, teaching methodology and psycholinguistics and has published and presented papers in these areas.

Seyyed Mahdi Erfani received his MA in linguistics in 1993 from Ferdousi University, Mashad, Iran. He is currently a lecturer of Damghan University, Iran. His interests include ESP, machine translation, materials development \& sociolinguistics and has published and presented papers in these areas.

Hossein Davari received his MA in linguistics in 2005 from Tarbiat Modares University (TMU), Tehran, Iran, and his MA in TEFL in 2010 from Payame Nour University (PNU) and currently is a PhD candidate in linguistics at TMU. He is a lecturer of PNU, Damghan, Iran. His interests include materials development, sociolinguistics, lexicography \& ESP and has published and presented papers in these areas. 